\title{
Spatial distribution and interspecific association patterns between Mansonia altissima A. Chev., Ceiba pentandra (L.) Gaertn and Triplochiton scleroxylon K. Schum. in a moist semi-deciduous forest
}

\author{
Adigla Appolinaire Wédjangnon ${ }^{1}$ [D * N. Bienvenue Sourou Kuiga ${ }^{1} \cdot$ Towanou Houêtchégnon $^{1}$. \\ Christine A. I. N. Ouinsavi ${ }^{1}$
}

Received: 4 July 2019 / Accepted: 17 December 2019 / Published online: 10 January 2020

(C) INRA and Springer-Verlag France SAS, part of Springer Nature 2019

\begin{abstract}
- Key message Mansonia altissima A. Chev. has an aggregated distribution at the juvenile life stage that becomes random at the mature life stage. Ceiba pentandra (L.) Gaertn could play the role of nurse plant in the management of $M$. altissima populations providing them a moderate forest shade in large gaps for early growth. M. altissima and Triplochiton scleroxylon K. Schum. displayed independent distribution patterns.

- Context M. altissima is a species with economic value found in moist semi-deciduous forests of tropical Africa. The analysis of spatial distribution patterns can help to understand the ecology of this species in forest stands dominated by emergent pioneer tree species like C. pentandra and T. scleroxylon.

- Aims To assess the spatial distribution patterns of M. altissima and spatial relationships with C. pentandra and T. scleroxylon in their natural habitat.

- Methods We investigated the spatial patterns of the three species during three life stages; juvenile (immature trees), premature (trees with minimum flowering diameter) and mature (trees with minimum fruiting diameter). Diameter at breast height (DBH) was measured and geographical coordinates of trees were recorded within ten one-ha plots, divided into sixteen subplots $\left(625 \mathrm{~m}^{2}\right)$. We computed the L(r) function, normalized from Ripley’s K(r) function to detect aggregated, random or regular distribution patterns. - Results Aggregations were detected in juvenile and premature M. altissima. Size and scales of spatial aggregation were inversely proportional to the DBH size. $M$. altissima and C. pentandra displayed interspecific association patterns at the similar life stages. Both species were positively associated within a radius $\geq 3 \mathrm{~m}$. No positive association was detected between M. altissima and T. scleroxylon. - Conclusion Interspecific association patterns between M. altissima and C. pentandra suggest that $C$. pentandra could be used as a nurse tree in reforestation and management practices of $M$. altissima populations.
\end{abstract}

Keywords Life stages · Spatial distributions · Ripley's L-function · Mansonia altissima $\cdot$ Ceiba pentandra $\cdot$ Triplochiton scleroxylon

\section{Handling Editor: Bruno Fady}

Contributions of the co-authors

N. Bienvenue Kuiga Sourou and Towanou Houêtchégnon have contributed to install the plots and to data collection in the forest and to database management. Christine A. I. N. Ouinsavi has supervised the work (data collection and analysis), review of drafts and manuscript improvements.

Adigla Appolinaire Wédjangnon

wedjangnon_app@yahoo.com

1 Laboratoire d'Etudes et de Recherches Forestières (LERF), Faculté d'Agronomie, Université de Parakou, 03BP 123 Parakou, Benin

\section{Introduction}

In a forest stand, spatial distribution of a species can be aggregated, random or regular (Du et al. 2017). These spatial distribution and association patterns of populations within plant communities are affected by various ecological or evolutionary processes such as niche segregation (Pielou 1962), habitat heterogeneity (Harms et al. 2001), differential predation (Janzen 1970; Connell 1971), neighborhood competition (Le et al. 2016; Getzin et al. 2006), dispersal limitation (Thioulouse et al. 1997), shade tolerance (Zhang et al. 
2013), regeneration (Cheng et al. 2014) and life history of populations (Qi et al. 2016).

Numerous studies of spatial distribution patterns showed that in heterogeneous forest stands (in terms of diversity and size of individuals) a tree is in competition with its immediate neighbors to access nutritive resources (Liu et al. 2014; Barot et al. 1999; Connell et al. 1984) leading to changes in spatial distribution patterns of the species. Competitive effects are detected through significant positive correlations between the size of trees and segregation distances of immediate neighbors (Pielou 1962). However, immediate neighbors are not inevitably competitors during all life stages of a species. They can act as facilitators in species with different shade tolerances and growth forms (Ledo 2015). Agyeman et al. (2016) found that the richness and abundance of timber species seedlings and saplings are mainly due to the presence of facilitating pioneer tree species.

To understand spatial distribution patterns, spatial distribution indices like Blackman's index (Blackman 1942) and Green's index (Green 1966) were used for a long time. These indices are giving a general idea of the type of spatial distribution in a forest stand, but cannot inform both on aggregation scale and location of a tree among neighbors (distance between two objects). This information is important to know the spatial scales of plant associations with different life strategies (Omelko et al. 2018). It can be generated using Ripley's $K$-function (Ripley 1977) that is an efficient indicator of spatial patterns (Marcon 2010; Cressie 1993; Diggle 1983). Ripley's $K$-function allows the analysis of spatial distribution patterns at several spatial scales and the detection mixed processes (association and repulsion at some scales) (Fonton et al. 2012; Fajardo et al. 2006). Since reforestation with native species may strongly contribute to the regeneration or restoration of degraded forests (Omelko et al. 2018; Agyeman et al. 2016), such analyses are important in forest management since they could improve our understanding of the role of pioneer species in maintaining plant diversity. They should enable a reasoned choice about distances between conspecific or heterospecific trees for ecological restoration of habitats and sustainable management of threatened species.

Although Mansonia altissima (Malvaceae) has the status of least concern (Botanic Gardens Conservation International and IUCN SSC Global Tree Specialist Group 2018), Mansonia altissima var. altissima A. Chev. is an overexploited and endangered variety of economic value (African Regional Workshop 1998). It grows naturally in moist semi-deciduous forests of tropical Africa. It is known to be a non-pioneer light-demanding (Agyeman et al. 1999; Veenendaal et al. 1996) while seedlings are known to grow in forest shade (Gyimah and Nakao 2007; Hawthorne 1995). The species is hermaphrodite but seems to be pollinated by insects (Akinnagbe et al. 2010). M. altissima is a popular West African timber tree that is also used as a substitute for American black walnut. It is popular for various uses in house building (Wédjangnon et al. 2016a), joinery as well as bark extracts used in therapeutic and medicinal fields (Adeoti et al. 2016). In Benin, it is only found in one moist semi-deciduous forest where it is critically endangered (Wédjangnon et al. 2016b; Neuenschwander et al. 2011) due to human activities and land property conflicts. Thus, management, restoration and conservation of this species increasingly required. It coexists with several other large size heterospecific pioneer tree species such as Ceiba pentandra (L.) Gaertn. (Malvaceae) and Triplochiton scleroxylon K. Schum. (Malvaceae) in plant communities of moist semideciduous forests in Benin.

The spatial patterns of these species substantially differ according to their size (Ligot et al. 2019; De Madron 2003), age and reproductive stages (Ouédraogo et al. 2018). It is therefore important to take life stages into account, taking the diameter class as a surrogate of life stage (Omelko et al. 2018; Ledo 2015; Li et al. 2008). Thus, forest stands are conventionally divided into two groups: juveniles $(<10 \mathrm{~cm} \mathrm{dbh})$ and adults $(\geq 10 \mathrm{~cm} \mathrm{dbh})$. However, tree species have not the same growth rate, diameter size and reproductive size. Therefore, the knowledge of the biology (reproductive size, growth rate) of the studied species is an important criterion to define similar life stages. Some studies accessed the reproductive size (Ouédraogo et al. 2018; De Madron and Daumerie 2004) and growth rate (Ligot et al. 2019; De Madron 2003) of the three species. The reproductive size and growth rate vary strongly among these three species. M. altissima can fructify at $18 \mathrm{~cm}$ diameter while, the minimum fruiting diameter for T. scleroxylon is $45 \mathrm{~cm}$ (Ouédraogo et al. 2018). De Madron and Daumerie (2004) showed that the diameter of M. altissima intervenes only slightly in fruiting. In contrast, fruiting diameter for T. scleroxylon varies strongly across sites (Ouédraogo et al. 2018). Moreover, C. pentandra and T. scleroxylon grow faster than $M$. altissima with annual diameter increments ranging up to $3 \mathrm{~cm} \mathrm{year}^{-1}$ (Duvall 2011), $1.63 \mathrm{~cm}$ year $^{-1}$ (Ligot et al. 2019) and $0.93 \mathrm{~cm} \mathrm{year}^{-1}$ (De Madron 2003) respectively. The largest radial growth rate is reached for trees with a dbh below $20 \mathrm{~cm}$ in M. altissima, and between 20 and $60 \mathrm{~cm}$ in T. scleroxylon (Ligot et al. 2019).

The main objective of this work is to assess the spatial distribution patterns of M. altissima trees and spatial relationships with these two pioneer tree species. The following questions were addressed: what is the spatial distribution pattern of M. altissima during the different life stages of the species? How does $M$. altissima coexist with these two dominant pioneers in its habitat? How do association patterns change with life stages of the species?

\section{Material and methods}

\subsection{Study area}

This study was conducted in the moist semi-deciduous forest of Adakplamè $\left(2^{\circ} 33^{\prime}-2^{\circ} 35^{\prime}\right.$ north and $7^{\circ} 27^{\prime}-7^{\circ} 29^{\prime}$ east) in 
the district of Kétou. The climate of this habitat is subequatorial. The rainfall is bimodal with about $1300 \mathrm{~mm} \mathrm{year}^{-1}$. The soil is weakly desaturated ferralitic above sandy-clay sediment, the clay contents of which increase according to depth. The vegetation is dominated by dense forest stands and some savannas and woodlands. This habitat that extends over 738 ha is a sacred grove. Its management is regulated by religious principles which are materialized across prohibitions, prescriptions and ritual practices. The dense forest stand constitutes a conservation area for several endangered species in Benin. Two plant communities were identified. One is dominated by Ceiba pentandra and Mansonia altissima and the second is dominated by Ricinodendron heudelotii (Baill.) Pierre ex Heckel and Triplochiton scleroxylon (Amanoudo et al. 2018). The presence of $C$. pentandra, M. altissima and T. scleroxylon is a positive indicator of soil fertility (Medjibe et al. 2011).

\subsection{Sampling}

The sampling design was constituted by ten (10) forest dynamics plots installed into two different plant communities (Amanoudo et al. 2018). Each one-ha plot was divided into sixteen (16) consecutive subplots, $625 \mathrm{~m}^{2}(25 \mathrm{~m} \times 25 \mathrm{~m})$. Previous investigations had shown that plots of one-ha size are reasonably suitable in the sudanian zone of Benin (Fonton et al. 2011).

\subsection{Data collection}

In each subplot, all juvenile individuals of $M$. altissima, $C$. pentandra and T. scleroxylon with a diameter $\geq 1 \mathrm{~cm}$ were measured with an electronic Vernier caliper (Kreator Stainless Hardened), while adult trees (trees with a circumference larger than $31 \mathrm{~cm}$ at $1.30 \mathrm{~m}$ above ground) were measured with a metric tape. The diameter measurement for adult trees of $C$. pentandra and T. scleroxylon was made above buttresses. The position of each tree was determined into two orthonormal vectors whose origin was fixed to upper left corner of each subplot.

\subsection{Data analysis}

\subsubsection{Distribution of trees in life stages}

Diameter distribution models for the three species were established and adjusted to the Weibull distribution curve in order to estimate historical parameters (shape and scale) of diameter distribution within each population. The software Minitab 16 was used to perform this analysis. The DBH of trees were classed into three functionally similar life stages according to the biological variables such as minimum flowering and fruiting diameter (Ouédraogo et al. 2018), diameter limit and annual growth rate (Ligot et al. 2019; De Madron 2003).

Mansonia altissima: Juvenile $(<10 \mathrm{~cm})$, Premature $(10$ $20 \mathrm{~cm})$, Mature $(>20 \mathrm{~cm})$.

Triplochiton scleroxylon: Juvenile $(<40 \mathrm{~cm})$, Premature $(40-70 \mathrm{~cm})$, Mature $(>70 \mathrm{~cm})$.

Ceiba pentandra: Juvenile $(<50 \mathrm{~cm})$, Premature $(50$ $80 \mathrm{~cm})$, Mature $(>80 \mathrm{~cm})$.

Juveniles are immature trees. Prematures are trees with minimum flowering diameter. Matures are trees with minimum fruiting diameter.

\subsubsection{Simulation of uni and bivariate spatial patterns}

Ripley's K(r) function (Ripley 1977) is a reliable informer of the spatial pattern (Marcon 2010; Diggle 1983; Cressie 1993). It is commonly used in point process analysis to detect the spatial distribution of species in a plant community (Fonton et al. 2012; Condit et al. 2000). However, the interpretation of $\mathrm{K}(\mathrm{r})$ function is not very easy because of its reference value $\pi^{2}$ and its hyperbolic graphical representation. A normalized function of $\mathrm{K}(\mathrm{r})$ was then proposed by Besag (1977) whose reference value is 0 (Pelissier and Goreaud 2015). This normalized function
Table 1 Dendrometric characteristics of the three species in the moist semi-deciduous forest of Adakplamè

\begin{tabular}{lccccccc}
\hline & $\mathrm{N}$ & $\mathrm{n}$ & DBHmin & DBHmax & Juvenile & Premature & Mature \\
\hline Mansonia altissima & 479 & 35 & 1.06 & 53.8 & $<10 \mathrm{~cm}$ & $\begin{array}{l}10-20 \mathrm{~cm} \\
(31.7 \%)\end{array}$ & $\begin{array}{l}(14.8 \%) \\
(53.4 \%)\end{array}$ \\
Triplochiton scleroxylon & 216 & 16 & 7.18 & 94.2 & $\begin{array}{l}<40 \mathrm{~cm} \\
(30-70 \mathrm{~cm}\end{array}$ & $>70 \mathrm{~cm}$ \\
Ceiba pentandra & 152 & 9 & 5.43 & 143.2 & $<50 \mathrm{~cm}$ & $50-80 \mathrm{~cm}$ & $>80 \mathrm{~cm}$ \\
& & & & & $(24.3 \%)$ & $(52.6 \%)$ & $(23.0 \%)$ \\
\hline
\end{tabular}

$\mathrm{N}$ : total number of trees; $\mathrm{n}$ : average number of trees per plot; DBHmin: minimum diameter at breast height; DBHmax: maximum diameter at breast height 
noted $\mathrm{L}(\mathrm{r})$ enables to stabilize the $\mathrm{K}(\mathrm{r})$ function variance and makes it easy to interpret the curves. Indeed, spatial distribution and intra - interspecific association patterns of the target species were studied by computation of $\mathrm{L}(\mathrm{r})$ function estimations (Besag 1977). Univariate spatial patterns were simulated for one object using $\mathrm{L}_{11}(\mathrm{r})$ function while, bivariate spatial patterns were simulated for two various objects using intertype $\mathrm{L}_{12}(\mathrm{r})$ function, which characterizes the spatial interaction between points of two different types (for example trees of two different species) within the same plant community (Diggle 1983). Confidence limits were computed under the null hypothesis of a complete spatial random distribution (CSR) with 199 Monte Carlo simulations (Besag 1977) and fifth lowest and highest values were used to build the simulation envelopes (Wiegand 2014). The process was repeated for various scales from 0 to $50 \mathrm{~m}$. The theoretical values under the null hypothesis as well as confidence limits and CSR departure probabilities were estimated at $1 \mathrm{~m}$ intervals. Analyses were performed with Programita software (Wiegand and Moloney 2014).

Under these conditions, the distribution of an object is aggregated to scale $r$ when the $L_{11}(r)$ function curve is positive (above confidence limits), it is regular when the function curve is negative (below confidence limits) and random when it is inside. Reciprocally, when the intertype function curve $\mathrm{L}_{12}(\mathrm{r})$ is above or below or inside confidence limits, it respectively indicates the attraction, repulsion or independence of two objects.

\section{Results}

\subsection{Dendrometric characteristics and diameter distribution models}

Dendrometric characteristics of species are shown in Table 1. Modeled distribution of diameter for three species in the forest stand is shown in Fig. 1. M. altissima displays a lower diameter than both dominant pioneer tree species as indicated by the shape and scale of the diameter distribution. Weibull's distribution curve shows an exponential descending distribution for M. altissima and a bell-shape distribution for C. pentandra and T. scleroxylon. The shape parameter ranked between 1 and 3.6 showing the predominance of trees with low or middle diameter. The larger value of shape parameter for T. scleroxylon (1.81) and C. pentandra (2.34) compared to M. altissima (1.11), highlights the abundance of trees with smaller size in this population of M. altissima and the abundance of trees with higher size in populations of $C$. pentandra and T. scleroxylon. Individuals with $\mathrm{DBH}<10 \mathrm{~cm}$ were almost lacking in C. pentandra (2 stems) and T. scleroxylon (5 stems).


Fig. 1 Modeled distribution of diameter at $1.30 \mathrm{~m}$ above ground for Mansonia altissima, Ceiba pentandra and Triplochiton scleroxylon in the study area

\subsection{Spatial distribution patterns of $M$. altissima}

Distribution maps of the three species within 10 plots are shown in Fig. 2. Univariate analysis performed from location of $M$. altissima within each plot $(100 \times 100 \mathrm{~m})$ showed an aggregated distribution of low intensity at scale $0-15 \mathrm{~m}$ (Fig. 3). However, when we consider the life stages separately, the spatial distribution of M. altissima varied in the three life stages (Figs. 2 and 3). In fact, juveniles of M. altissima display 
Fig. 2 Spatial distribution patterns of Mansonia altissima, Ceiba pentandra and

Triplochiton scleroxylon according to their life stages within a plot in the moist semideciduous forest of Adakplamè The plot was selected in the conservation core area to avoid the influence of anthropogenic disturbance factors


Premature

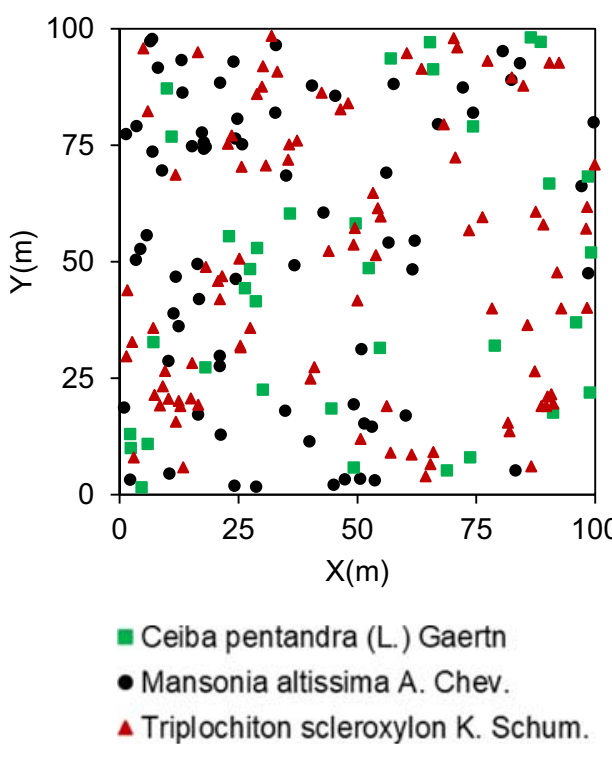

Mature

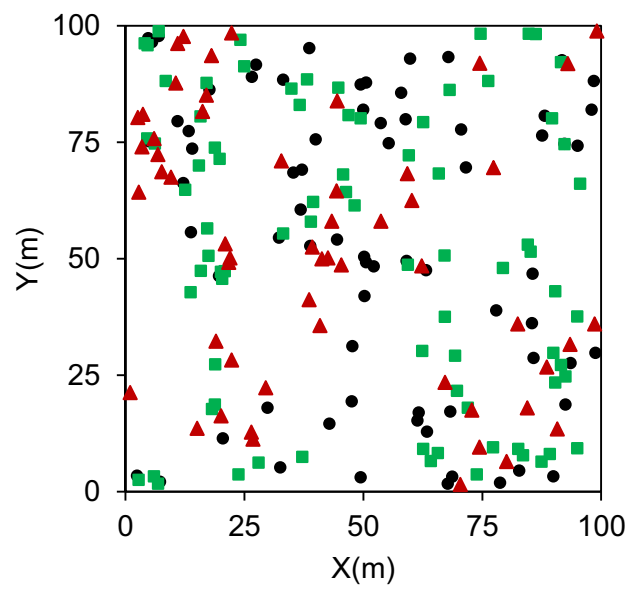

an aggregated distribution at scale $0-14 \mathrm{~m}$ whose peak is located at $6 \mathrm{~m}$ while, premature trees display an aggregated distribution at scale $2-7 \mathrm{~m}$ and mature trees, a random distribution (Fig. 3).

\subsection{Intraspecific association patterns of $M$. altissima}

Bivariate analysis of spatial associations between life stages of M. altissima are shown in Fig. 4. Significant attractions of low intensity were observed between juvenile and premature and then premature and mature. In fact, juvenile and premature trees showed a positive attraction at scale $0-3 \mathrm{~m}$ with an attraction peak at $2 \mathrm{~m}$ while, premature and mature are positively associated to the spatial scales 2-6 m. On the other hand, the distribution of juvenile $M$. altissima was independent from mature trees (reproductive) with a repulsion trend at scale 5-12 m.

\subsection{Interspecific association patterns between $M$. altissima and C. pentandra}

Bivariate analyses of spatial association patterns between M. altissima and $C$. pentandra are shown in Fig. 5. Overall, $M$. altissima and $C$. pentandra showed an independent distribution patterns at all spatial scales (Fig. 5). However, positive attractions between M. altissima and C. pentandra occured mainly among individuals from functionally similar life stages (or even life stage). Thus, juveniles of $M$. altissima and $C$. pentandra showed a significant positive association of lower intensity at scale $3-$ $5 \mathrm{~m}$ and higher intensity over $45 \mathrm{~m}$ whereas negative attractions (repulsion) were observed among juveniles of $M$. altissima and both prematures and matures life stages of $C$. pentandra. M. altissima (juveniles) and $C$. pentandra (prematures) showed a repulsion at scale 15-23 $\mathrm{m}$ and 7- 

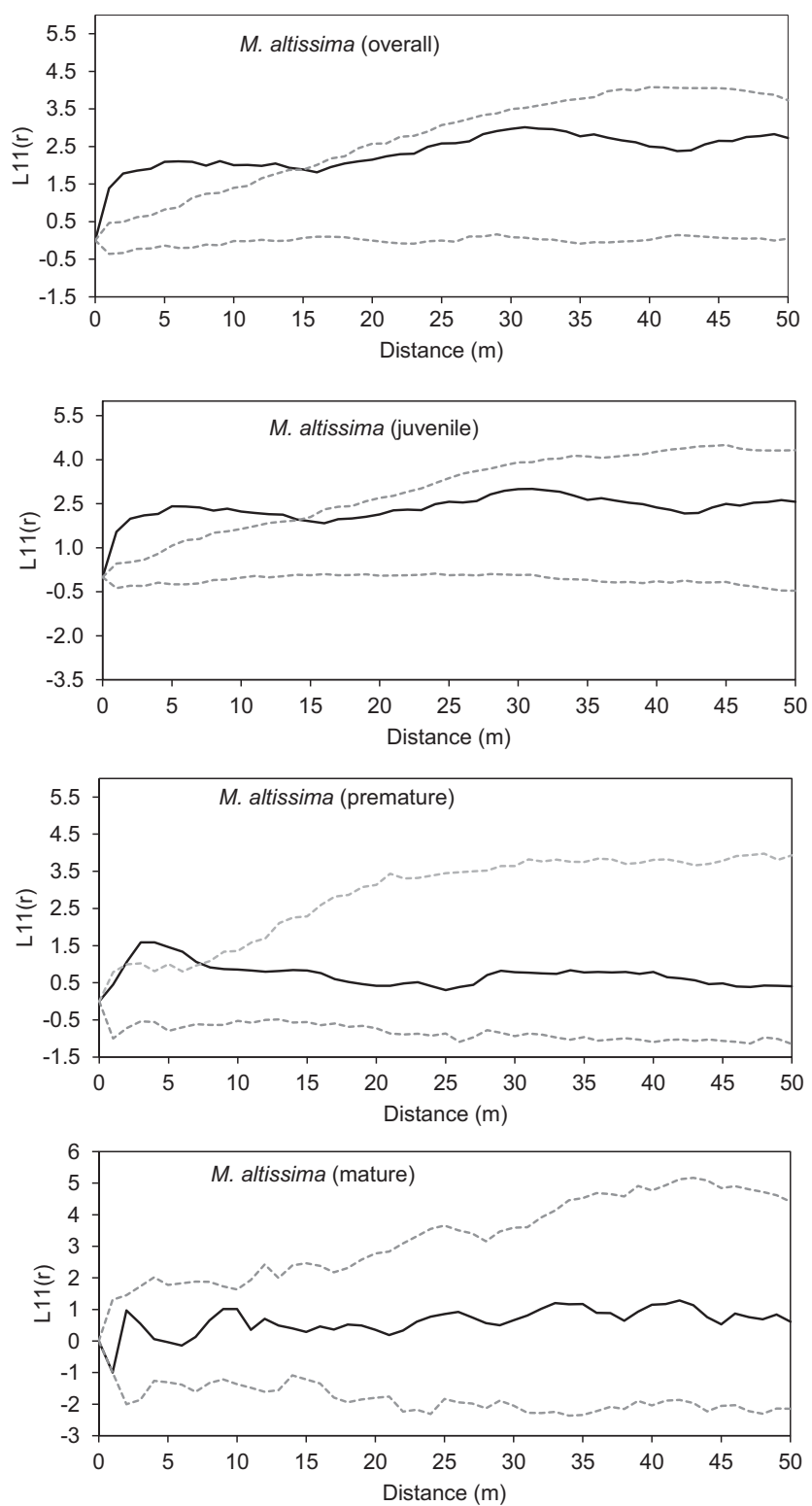

Fig. 3 Spatial distribution patterns of Mansonia altissima in the moist semi-deciduous forest of Adakplamè according to its life stages. Black curves are observed patterns and dotted lines are 95\% confidence limits for 199 Monte Carlo simulations. Curves above upper limit show aggregate, curves below lower limit show regularity and curves within limits show random of the trees from same life stage

$11 \mathrm{~m}$ for $M$. altissima (juveniles) and C. pentandra (matures).

\subsection{Interspecific association patterns between $M$. altissima and $T$. scleroxylon}

Bivariate analyses of spatial association patterns between M. altissima and T. scleroxylon are shown in Fig. 6. Overall, M. altissima displayed an independent distribution pattern from T. scleroxylon during the three life stages. Thus, the
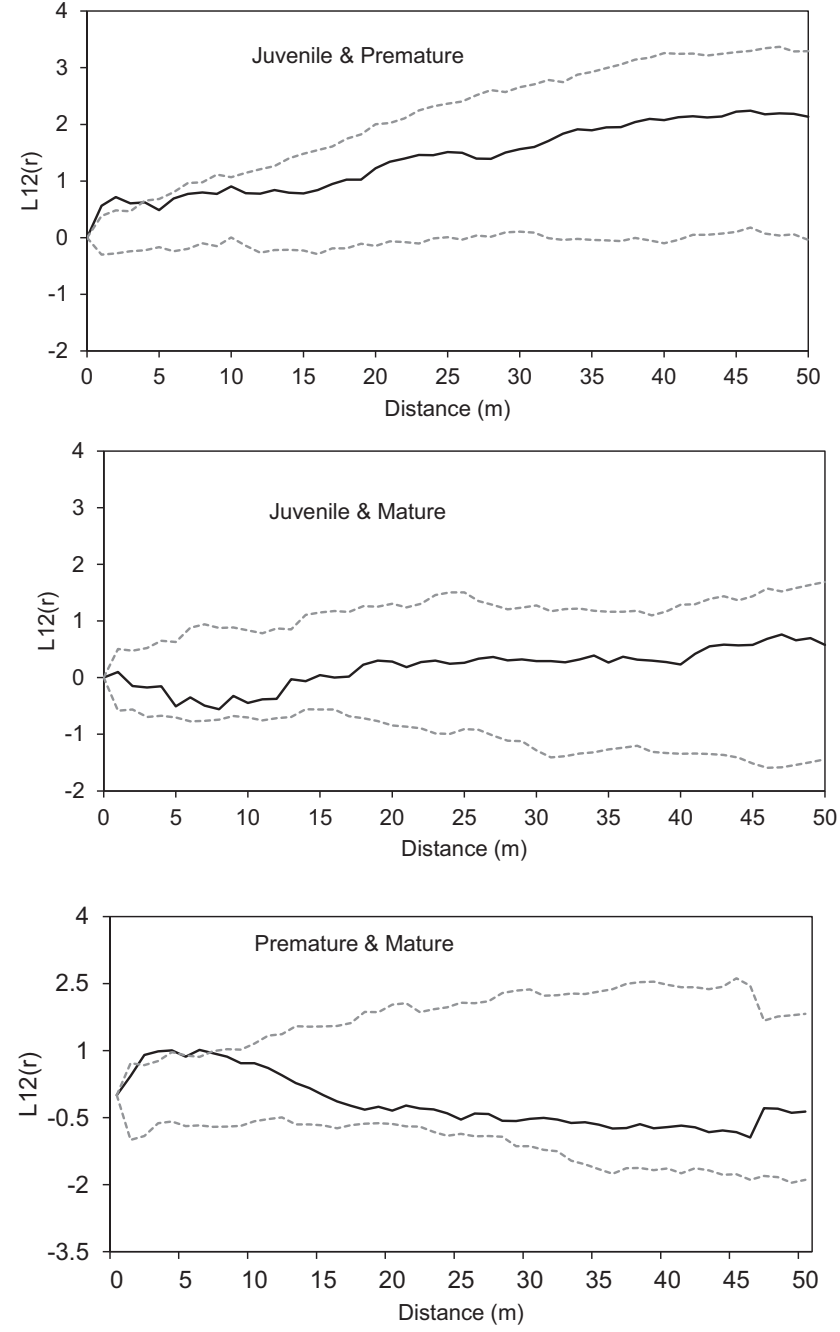

Fig. 4 Intra-species association patterns of Mansonia altissima in the moist semi-deciduous forest of Adakplamè. Black curves are observed patterns and dotted lines are 95\% confidence limits for 199 Monte Carlo simulations. Curves above upper limit show association, curves below lower limit show repulsion and curves within limits show independence of the individuals with different life stages

distribution pattern of M. altissima did not depend on that of T. scleroxylon in the moist semi-deciduous forest.

\section{Discussion}

\subsection{Diameter distribution and regeneration status of the three species}

The diameter size of plant species in a forest stand follows two types of distribution; exponential descending and bell-shape distribution. These two types of distribution are often used to characterize the behavior of species (Dupuy et al. 1998). An exponential descending distribution is characteristic of typically sciaphilous species, while a bell-shape distribution is characteristic of typically heliophilous species (Dupuy et al. 



Fig. 5 Inter-species association patterns of Mansonia altissima and Ceiba pentandra in the moist semi-deciduous forest of Adakplamè according to their life stages. Black curves are observed patterns and dotted lines are 95\% confidence limits for 199 Monte Carlo simulations. Curves above

upper limit show association, curves below lower limit show repulsion and curves within limits show independence of the two species. J, P, M denote juveniles, prematures and matures respectively 
Fig. 6 Inter-species association patterns of Mansonia altissima and Triplochiton scleroxylon in the moist semi-deciduous forest of Adakplamè according to their life stages. Black curves are observed patterns and dotted lines are $95 \%$ confidence limits for 199 Monte Carlo simulations. Curves above the upper limit show association, curves below lower limit show repulsion and curves within limits show independence of the two species. $J, P$, $M$ indicate juveniles, pre-matures and matures respectively
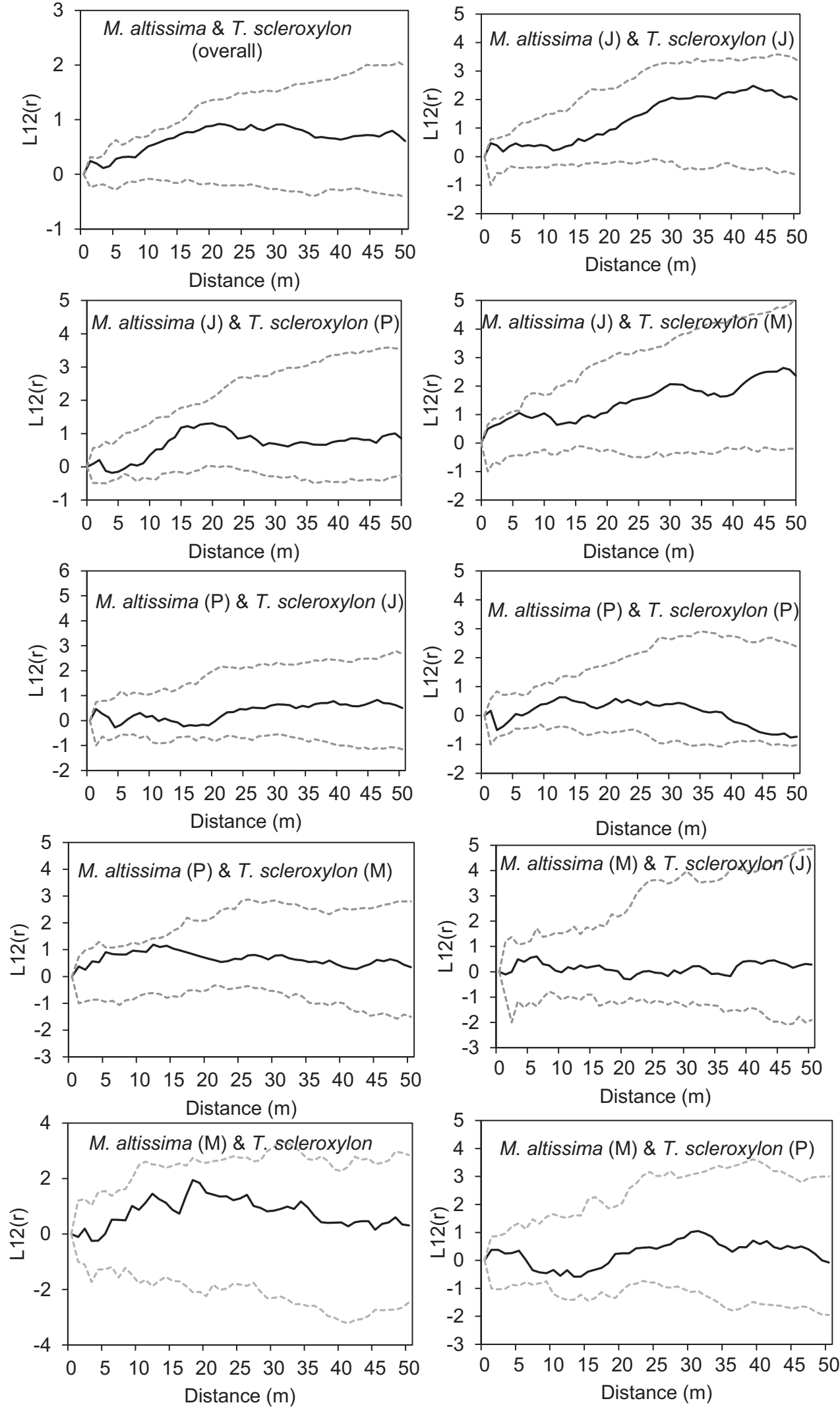

1998). M. altissima is a non-pioneer species (Veenendaal et al. 1996) whose seedlings are known to grow and establish in forest shade during the first years (Gyimah and Nakao 2007; Hawthorne 1995). This change of ecological requirements 
during the development of $M$. altissima seedlings may explain the abundance of juveniles comparatively with premature trees in the dense forest stand. The bell-shape distribution for $C$. pentandra and T. scleroxylon suggests poor regeneration.

The almost lack of regeneration $(<10 \mathrm{~cm} \mathrm{dbh})$ for C. pentandra and T. scleroxylon reveals different life histories of these species compared to M. altissima. Populations of C. pentandra and T. scleroxylon are older than the population of M. altissima in the forest. Nevertheless, the reproduction of T. scleroxylon seems to be supra-annual with irregular fructifications (Palla and Louppe 2002; Jones 1974) which may further hamper its regeneration (Ligot et al. 2019). C. pentandra is known to be gap depending for its regeneration (Sokpon 1995). It has very few seedlings in dense forest stands as well as large gaps dominated by undergrowth species (Sokpon 1995). Particularly, C. pentandra is one of species that produce many seedlings, which are not able to live under dense canopies and require from first years both sunlight and large gaps where they can grow rapidly. So, the dense canopy of the forest could hamper the growth and survival of $C$. pentandra seedlings.

\subsection{Spatial relationships between the three species in the forest}

Tree species generally are less aggregated with increasing size-class (Zhang et al. 2013; Condit et al. 2000) suggesting that larger trees are more competitive than smaller ones (Zhang et al. 2013). It is also supported that when the competition is important, adult or mature trees are less aggregated than juvenile and premature trees due to the recruitment limit of adults among conspecific or heterospecific large trees (Murrell 2009). The ecological requirements of plants during their life stages can result in a competition at some life stages meaning a decrease of aggregation in large size-classes. It is the case of non-pioneer and light-demanding plants that emerge. The competition to access light resource after juvenile stage, should remove individuals that are nearby neighbors meaning a decrease of aggregation at premature and mature stages. It can increase distances between individuals with different life stages and mean random distributions (Du et al. 2017). The aggregated distribution of juveniles and premature M. altissima and random distribution of mature M. altissima in the forest could be due to the aggregation of smaller trees in forest shade and the change of requirements in light resource at the adult stage. After juvenile life stage, $M$. altissima requires light to emerge.

M. altissima displayed an independent distribution pattern between juvenile and mature trees. This distribution pattern confirms its status of non-pioneer and light-demanding. Thus, the growth conditions required for M. altissima at the mature stage would not facilitate seedling establishment and early growth. Interspecific association patterns displayed in $M$. altissima and $C$. pentandra indicated that the functionally similar life stages are positively associated. C. pentandra particularly colonizes large gaps and becomes emergent in mature forest stands with larger growth rates (Duvall 2012). That would allow seedlings of $M$. altissima within periphery to find the forest shade required for their establishment and survival. This suggests that $C$. pentandra could play the role of nurse plant in the management of $M$. altissima populations to create a moderate shade and increase seedlings establishment and survival chance. Moreover, $C$. pentandra is an evergreen tree whose shade could facilitate or improve seedlings survival during the dry season. In contrary, T. scleroxylon is a deciduous tree. This could mean adverse conditions for seedlings survival during the dry season leading to the independent distribution patterns in M. altissima and T. scleroxylon.

\section{Conclusion}

Our study found interspecific associations between $M$. altissima and $C$. pentandra, which suggest that C. pentandra, as pioneer species, can play an important role in improving the establishment and survival conditions of M. altissima in plant communities. Therefore, $C$. pentandra could be used as a nurse tree in reforestation and management practices of $M$. altissima populations. The study provides a scientific basis for a reasoned choice of distances between the plants of M. altissima and C. pentandra. Silvicultural treatments such as thinning could be required after juvenile life stage to increase the survival and growth rates of $M$. altissima. M. altissima and T. scleroxylon displayed independent distribution patterns, which meant a lack of interaction between the two species in the three life stages. The results shown in this paper can also be implemented to more deeply elucidate the role of pioneer species in plant communities.

Acknowledgements This paper is based on the $\mathrm{PhD}$ thesis of the corresponding author, written as partial fulfillment for the $\mathrm{PhD}$ degree in Natural Resources Management at University of Parakou, Benin. The authors are grateful to all scientists from Laboratoire d'Etudes et de Recherches Forestières who contributed to this study. They are grateful to the anonymous reviewers whom strongly contributed to improve the quality of this paper. This research did not receive any specific grant from funding agencies in the public, commercial or not-for-profit sectors.

Data availability The datasets generated and/or analyzed during the current study together with the associated metadata are available in the Advanced Ecological Knowledge and Observation System (AEKOS) portal (Wédjangnon et al. 2019) at https://doi.org/10.25901/ 5 dce $7 f 2714885$

\section{Compliance with ethical standards}

Conflicts of interest The authors declare that they have no conflict of interest. 


\section{References}

Adeoti MF, Bidie P, Camara-Cisse M, Monteomo GF, Kolia KI, Gogahy K, Djaman AJ, Dosso M (2016) Acute toxicity and indirect effects on the NA+/K+ ATPase pump of chloroform extract of Mansonia altissima (Sterculiaceae) in rabbits. European J Biotechnol Biosci 4: 29-33

African Regional Workshop (1998) Conservation \& Sustainable Management of Trees, Zimbabwe, July 1996. Mansonia altissima var altissima The IUCN Red List of Threatened Species: e.T32283A9686553. https://doi.org/10.2305/IUCN.UK.1998. RLTS.T32283A9686553.en. Accessed 08 June 2019

Agyeman VK, Swaine MD, Thompson J (1999) Responses of tropical forest tree seedlings to irradiance and the derivation of a light response index. J Ecol 87:815-827. https://doi.org/10.1046/j.13652745.1999.00400.x

Agyeman VK, Addo-Danso SD, Kyereh B, Abebrese IK (2016) Vegetation assessment of native tree species in Broussonetia papyrifera-dominated degraded forest landscape in southern Ghana. Appl Veg Sci 19:498-507. https://doi.org/10.1111/avsc. 12241

Akinnagbe A, Gailing O, Finkeldey R (2010) Genetic diversity of Mansonia altissima A. Chev. under different regimes of human impact in the Akure Forest reserve, Nigeria. Forest Stud China 12:193200. https://doi.org/10.1007/s11632-010-0407-5

Amanoudo M-J, Gbemavo CDSJ, Ouinsavi CNAI (2018) Assessing the floristic potential of Adakplamè sacred grove in South Benin. IJSR 7:1062-1067. https://doi.org/10.21275/ART20181581

Barot S, Gignoux J, Menaut J-C (1999) Demography of a savanna palm tree: predictions from comprehensive spatial pattern analyses. Ecology 80:1987-2005. https://doi.org/10.1890/0012-9658(1999) 080[1987:DOASPT]2.0.CO;2

Besag J (1977) Contribution to the discussion on Dr Ripley's paper. J R Stat Soc 39:193-195

Blackman G (1942) Statistical and ecological studies in the distribution of species in plant communities: dispersion as a factor in the study of changes in plant populations. Ann Bot 6:351-370

Botanic Gardens Conservation International (BGCI) \& IUCN SSC Global Tree Specialist Group (2018) Mansonia altissima. The IUCN Red List of Threatened Species: e.T62753A136113496. https://doi.org/10.2305/IUCN.UK.2018-2.RLTS. T62753A136113496.en. Accessed 08 June 2019

Cheng X, Han H, Kang F, Song Y, Liu K (2014) Point pattern analysis of different life stages of Quercus liaotungensis in Lingkong Mountain, Shanxi Province, China. J Plant Interact 9:233-240. https://doi.org/ 10.1080/17429145.2013.818167

Condit R, Ashton PS, Baker P, Bunyavejchewin S, Gunatilleke S, Gunatilleke N, Hubbell SP, Foster RB, Itoh A, Lafrankie JV (2000) Spatial patterns in the distribution of tropical tree species. Science 288:1414-1418

Connell JH (1971) On the role of natural enemies in preventing competitive exclusion in some marine animals and in rain forest trees. In: Den Boer PJ, Gradwell GR, Neuenschwander et al (eds) Dynamics of populations. Centre for Agricultural Publishing and Documentation, Wageningen, pp 298-312

Connell JH, Tracey J, Webb LJ (1984) Compensatory recruitment, growth, and mortality as factors maintaining rain forest tree diversity. Ecol Monogr 54:141-164. https://doi.org/10.2307/1942659

Cressie NA (1993) Statistics for spatial data. Wiley, New York, p 900

De Madron LD (2003) Accroissement diamétrique du bété et de l'iroko. Bois For Trop 275:83-87

De Madron LD, Daumerie A (2004) Diamètre de fructification de quelques essences en forêt naturelle centrafricaine. Bois For Trop 281:87-95
Diggle PJ (1983) Statistical analysis of spatial point patterns, vol 148. Academic Press, London

Du H, Hu F, Zeng F, Wang K, Peng W, Zhang H, Zeng Z, Zhang F, Song $\mathrm{T}$ (2017) Spatial distribution of tree species in evergreen-deciduous broadleaf karst forests in Southwest China. Sci Rep 7:15664. https:// doi.org/10.1038/s41598-017-15789-5

Dupuy B, Durrieu De Madron M, Pettrucci Y (1998) Sylviculture des peuplements naturels en forêt dense humide africaine. Acquis et recommandations. Bois For Trop 257(3):5-22

Duvall CS (2011) Ceiba pentandra (L.) Gaertn. In: Brink M \& AchiganDako EG, Neuenschwander et al. PROTA (Plant Resources of Tropical Africa / Ressources végétales de l'Afrique tropicale). Wageningen. Accessed 08 June 2019

Duvall CS (2012) Ceiba pentandra (L.) Gaertn. In: Brink M, AchiganDako EG (eds) Ressources végétales de l'Afrique tropicale 16. Plantes à fibres. [Traduction de: Plant Resources of Tropical Africa 16. Fibres. 2012]. Fondation PROTA, Wageningen, p 88

Fajardo A, Goodburn JM, Graham J (2006) Spatial patterns of regeneration in managed uneven-aged ponderosa pine/Douglas-fir forests of Western Montana, USA. For Ecol Manag 223:255-266. https://doi. org/10.1016/j.foreco.2005.11.022

Fonton NH, Atindogbe G, Hounkonnou NM, Dohou RO (2011) Plot size for modelling the spatial structure of Sudanian woodland trees. Ann For Sci 68:1315-1321. https://doi.org/10.1007/s13595-011-0111-1

Fonton NH, Atindogbe G, Fandohan B, Lejeune P, Ligot G (2012) Structure spatiale des arbres des savanes boisées et forêts claires soudaniennes: implication pour les enrichissements forestiers. Biotechnol Agron Soc Environ 16:429-440

Getzin S, Dean C, He FA, Trofymow J, Wiegand K, Wiegand T (2006) Spatial patterns and competition of tree species in a Douglas-fir chronosequence on Vancouver Island. Ecography 29:671-682. https://doi.org/10.1111/j.2006.0906-7590.04675.x

Green RH (1966) Measurement of non-randomness in spatial distributions. Popul Ecol 8:1-7

Gyimah R, Nakao T (2007) Early growth and photosynthetic responses to light in seedlings of three tropical species differing in successionalstrategies. New Forest 33:217-236. https://doi.org/10. 1007/s11056-006-9028-1

Harms KE, Condit R, Hubbell SP, Foster RB (2001) Habitat associations of trees and shrubs in a 50-ha neotropical forest plot. J Ecol 89:947959

Hawthorne W (1995) Ecological profiles of Ghanaian forest trees, vol 29. Oxford Forestry Institute, Department of Plant Sciences, University of Oxford, Oxford, p 345

Janzen DH (1970) Herbivores and the number of tree species in tropical forests. Am Natur 940:501-528

Jones N (1974) Records and comments regarding the flowering of Triplochiton scleroxylon K. Schum. Commonw For Rev 1:52-56

Le N, Thi D, Van Thinh N, Mitlöhner R (2016) Effect of disturbance regimes on spatial patterns of tree species in three sites in a tropical evergreen forest in Vietnam. IJFR. https://doi.org/10.1155/2016/ 4903749

Ledo A (2015) Nature and age of neighbours matter: interspecific associations among tree species exist and vary across life stages in tropical forests. PLoS One 11:1-17. https://doi.org/10.1371/journal. pone. 0141387

Li L, Wei SG, Huang ZL, Ye WH, Cao HL (2008) Spatial patterns and interspecific associations of three canopy species at different life stages in a subtropical forest, China. J Integr Plant Biol 9:1140 1150. https://doi.org/10.1111/j.1744-7909.2008.00690.x

Ligot G, Fayolle A, Gourlet-Fleury S, Daïnou K, Gillet JF, De Ridder M, Drouet T, Groenendijk P, Doucet JL (2019) Growth determinants of timber species Triplochiton scleroxylon and implications for forest management in Central Africa. For Ecol Manag 437:211-221. https://doi.org/10.1016/j.foreco.2019.01.042 
Liu Y, Li F, Jin G (2014) Spatial patterns and associations of four species in an old-growth temperate forest. J Plant Interact 9:745-753. https://doi.org/10.1080/17429145.2014.925146

Marcon E (2010) Statistiques spatiales avec applications à l'écologie et à l'économie. AgroParisTech

Medjibe V, Hall JS, Ashton MS, Harris D (2011) Distribution of selected timber species of a central African rain forest in relation to topography and soil heterogeneity: implications for forest management. J Sustain For 5:343-359. https://doi.org/10.1080/10549811.2011. 534030

Murrell DJ (2009) On the emergent spatial structure of size-structured populations: when does self-thinning lead to a reduction in clustering? J Ecol 97:256-266. https://doi.org/10.1111/j.1365-2745.2008. 01475.x

Neuenschwander P, Sinsin B, Goergen GE (eds) (2011) Protection de la nature en Afrique de l'Ouest: Une Liste rouge pour le Bénin. Nature conservation in West Africa: red list for Benin. IITA, Nigeria, p 365

Omelko A, Ukhvatkina O, Zhmerenetsky A, Sibirina L, Petrenko T, Bobrovsky M (2018) From young to adult trees: how spatial patterns of plants with different life strategies change during age development in an old-growth Korean pine-broadleaved forest. For Ecol Manag 411:46-66. https://doi.org/10.1016/j.foreco.2018.01.023

Ouédraogo DY, Doucet JL, Daïnou K, Baya F, Biwolé AB, Bourland N, Fétéké F, Gillet JF, Kouadio YL, Fayolle A (2018) The size at reproduction of canopy tree species in Central Africa. Biotropica 3:465-476. https://doi.org/10.1111/btp.12531

Palla F, Louppe D (2002) Obeché Montpellier: CIRAD-Forêt p 6

Pelissier R, Goreaud F (2015) Ads package for R: a fast unbiased implementation of the K-function family for studying spatial point patterns in irregular-shaped sampling windows. J Stat Softw 63:1-18. https://doi.org/10.18637/jss.v063.i06

Pielou E (1962) The use of plant-to-neighbour distances for the detection of competition. J Ecol 2:357-367

Qi L, Yang J, Yu D, Dai L, Contrereas M (2016) Responses of regeneration and species coexistence to single-tree selective logging for a temperate mixed forest in eastern Eurasia. Ann For Sci 73:449-460. https://doi.org/10.1007/s13595-016-0537-6
Ripley BD (1977) Modelling spatial patterns. J R Stat Soc Ser B Stat Methodol 39(2):172-212. https://doi.org/10.2307/2984796

Sokpon N (1995) Régénération naturelle dans les trouées de la forêt dense semi-décidue de Pobè, Sud-Est Bénin. Belg J Bot 1:13-32

Thioulouse J, Chessel D, Dole S, Olivier JM (1997) ADE-4: a multivariate analysis and graphical display software. Stat Comput 7:75-83

Veenendaal EM, Swaine MD, Lecha RT, Walsh MF, Abebrese IK, Owusu-Afriyie K (1996) Responses of west African forest tree seedlings to irradiance and soil fertility. Funct Ecol 10(4):501-511. https://doi.org/10.2307/2389943

Wédjangnon AA, Houètchégnon T, Ouinsavi C (2016a) Caractéristiques ethnobotaniques et importance socio-culturelle de Mansonia altissima A. Chev. au Bénin, Afrique de l'Ouest. J Anim Plant Sci 29:4678-4690

Wédjangnon AA, Houètchégnon T, Ouinsavi C (2016b) Ecological characterization and mass propagation of Mansonia altissima a. Chev. In the Guinean zone of Benin, West Africa. Int J Pure App Biosci 4(4): 15-25. https://doi.org/10.18782/2320-7051.2339

Wédjangnon AA, Sourou Kuiga BN, Houètchégnon T, Ouinsavi C (2019) A dataset on spatial distribution and association patterns of three species from moist semi deciduous forest. Version 15 November 2019. AEKOS. [dataset]. https://doi.org/10.25901/ 5 dce $7 f 2714885$

Wiegand T (2014) User manual for the Programita software, Department of Ecological Modelling, vol 15. Helmholtz Centre for Environmental Research - UFZ, Permoserstr, Leipzig, p 04318

Wiegand T, Moloney KA (2014) A handbook of spatial point pattern analysis in ecology. Chapman and Hall/CRC press, Boca Raton. https://doi.org/10.1002/bimj.201400174

Zhang Z, Hu G, Zhu J, Ni J (2013) Aggregated spatial distributions of species in a subtropical karst forest, southwestern China. J Plant Ecol 6:131-140. https://doi.org/10.1093/jpe/rts027

Publisher's note Springer Nature remains neutral with regard to jurisdictional claims in published maps and institutional affiliations. 